PAPER • OPEN ACCESS

\section{Digital transformation in society: key aspects for model development}

To cite this article: N V Morze and O V Strutynska 2021 J. Phys.: Conf. Ser. 1946012021

View the article online for updates and enhancements.
You may also like

Digital transformation of construction
$\frac{\text { organizations }}{\text { Vadim Koscheyev, Viktoriya Rapgof and }}$
Viktoriya Vinogradova
Tools for assessing the level of
$\frac{\text { development of digital technologies in }}{\text { Russia (on the example of the Far East) }}$
Nikolay Egorov, Grigoriy Kovrov, Irina
Nikolaeva et al.
Digital transformation of the Bulgarian
industry
Sibel Ahmedova

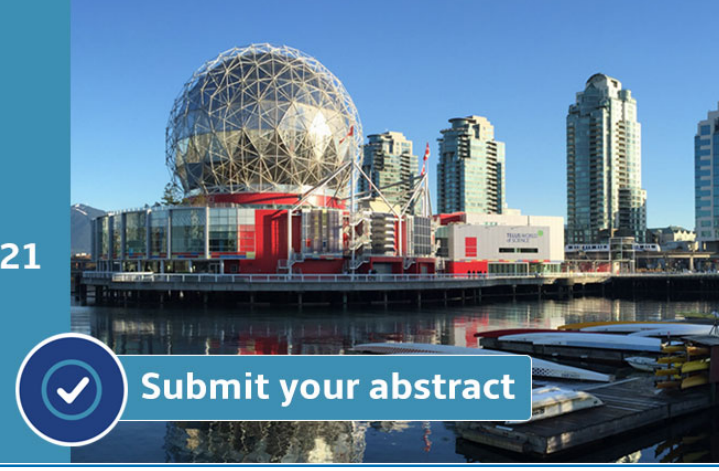




\title{
Digital transformation in society: key aspects for model development
}

\author{
N V Morze ${ }^{1}$ and O V Strutynska ${ }^{2}$ \\ ${ }^{1}$ Borys Grinchenko Kyiv University, 18/2 Bulvarno-Kudriavska Str., Kyiv, 04053, Ukraine \\ ${ }^{2}$ National Pedagogical Dragomanov University, 9 Pyrogova Str., Kyiv, 01601, Ukraine \\ E-mail: n.morze@kubg.edu.ua, o.v.strutynska@npu.edu.ua
}

\begin{abstract}
The paper is devoted to the analysis of the digital transformation processes that are currently taking place in the economy, production, education and society as a whole. The main reason digital transformation is impact of the digital technologies. Modern digital technologies, services and systems are extremely important for social development. One of the key issues for the implementation of digital transformation is changes in the way of thinking and requirements for the competencies of workers in the industry. First of all, it is connected with people's understanding of digital transformation processes and with their ability to use digital technologies effectively. For specifying Ukrainian educators' awareness level about digital transformation processes, there were conducted survey. Research results have shown that there is a need to increase their awareness level about digital transformation processes. Based on the analysis of the considered researches the authors have developed a generalized model of digital transformation for enterprises, businesses and educational institutions.
\end{abstract}

\section{Introduction}

The basis of modern society is digital technology: artificial intelligence, robotics, IoT, blockchain and $3 \mathrm{D}$ technologies, etc. [1-14].

An example of how digital technologies have become a part of our everyday life is the infographic (figure 1). It is developed according to the Internet portals Statista, Visual Capitalist, Business Insider, Gamespot, Techcrunch, Omnocode Agency, Doordash, Business of Apps, New York Times, Music Business Worldwide, INC., Hootsuite, Dustin Stout, Reddit, Uber, Amazon, Wox that demonstrate what happened within one minute of human activity with the use of digital technologies in 2020 [15].

The report of the consulting company Accenture (for 2017) identifies five new digital technologies that can transform global economic development [16]: Internet of Things (IoT), Artificial Intelligence (AI), Blockchain, Big Data, Robotic Process Automation (RPA).

The use of digital technologies is transforming business models, resulting in new products and services; the format of works is changing (outsourcing, online platforms, improved automation, robotics, etc.). Real-time work with digital data fundamentally changes the ways of management, production, sale and use of products [17].

Thus, modern digital technologies, services and systems are extremely important for social development. Their introduction into the activities of enterprises and organizations, engineering and technology, production and non-production processes allows to expand the range of goods and services, improve their quality and compliance with consumer demand, increase productivity 


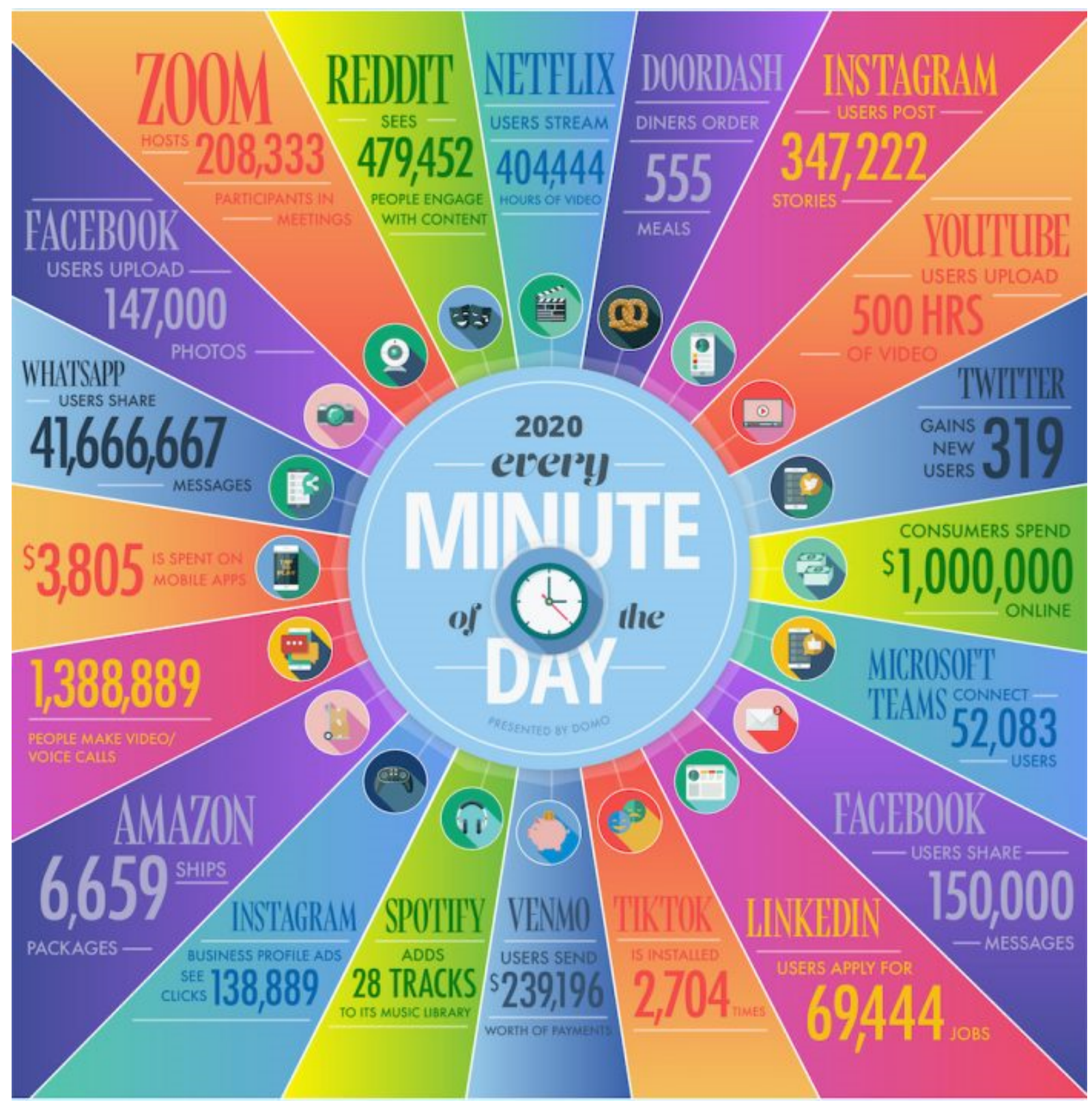

Figure 1. The results of human daily activities with the use of digital technologies within one minute in 2020. Source: data from https://www.domo.com/learn/data-never-sleeps-8.

and form new value-added chains. This will ensure growth and creation of jobs in all economy sectors (from the smallest traditional enterprises to the latest high-tech industries).

However, the education system is failing behind the general state of digital transformation in society. In our opinion, the main problem is the lack of understanding by the participants of the educational process of the institutions (higher, secondary and vocational) what is the difference between the use of digital technologies and innovations provided by the transformational changes that digital technologies bring to the educational process, and comprehension of concepts, structure, required and sufficient conditions and processes of digital transformation in general and in education in particular.

Paper goals. That is why, the purpose of this paper is to define Ukrainian educators' 
awareness level about digital transformation processes; to analyze and develop model of digital transformation that can have a place in enterprises, businesses and educational institutions.

\section{Research methods}

The authors have used the following research methods and tools for the investigation (2020).

Quantitative methods: 1) study and analysis of scientific monograph; 2) study and analysis of research papers; 3) study and analysis of documents about digital transformation; 4) analysis approaches for development digital transformation model; 5) (online) meeting, (video) conference, seminar, workshop, etc.

Qualitative methods: survey and interview of the Ukrainian educators to determine their awareness about digital transformation.

\section{Theoretical background}

The rapid development of digital technologies and, as a consequence, the digitalization of many sectors of society have led to the introducing such terms as "digitization", "digitalization", "digital transformation", which, in its turn, led later to the digital transformation concept [18-21].

Digital transformation is the use of digital technologies [22] to fundamentally increase the productivity and value of enterprises [23]. Now this is the focus of managers and employees of actively competing industries around the world. It is understood as a profound transformation of:

(i) production and organizational operations,

(ii) processes,

(iii) responsibilities of employees, and

(iv) models of their activities.

Digital transformation is due to the use of rapidly developing digital technologies and their accelerated impact on society. Such transformation takes into account the changes that have already happened, happening and will happen in the future [24]. The processes of digital transformation are affecting many areas of human activity. They are felt in all areas where there is mechanization and automation of data processing.

During the process of digital transformation, enterprises should:

- turn customers into partners,

- elicit the creative potential of staff,

- make all business processes flexible, scalable and natural,

- review or, if necessary, develop a new business model;

Not every innovation related to the introduction or modernization of information systems can be attributed to the digital transformation of the enterprise. In order to be "digital transformated", the implementation of an information system should [25]:

- lead to a fundamental (a qualitative step forward) increase in efficiency upon key performance indicators of work organization (improvement by many times),

- use modern digital technologies that are economical, scalable and flexible, adapted to rapid change (cloud computing, big data, artificial intelligence, virtual reality, etc.),

- be cross-cutting, i.e., affect several areas of transformation (customers and products, employees and processes, etc.),

- transform the enterprise into a learning organization $\rightarrow$ knowledge, 
- be accumulated, analyzed and applied by using digital technologies with the participation of staff and/or external experts.

The stages of digital transformation include:

1. Digitization.

2. Digitalization.

3. Digital transformation.

Digitization, digitizing is a technical process of converting analog data streams into digital format (in bits). The same interpretation of this concept is also followed by scientists from various fields (J. Beniger [26], S. Brennen [27], J. Bumann [28], V.D. Chekina [17], P.N. Edwards [29], T. Feldman [30], O.M. Harkushenko [17], D. Kreiss [27], S.I. Kniaziev [17], D.V. Lypnytskyi [17], M. Manoff [31], J.M. Owen [32], R. Pepperell [33], M.K. Peter [28], D. Robinson [34], D. Savi [35], J. Van Dijk [36], S. Verhulst [37], V.P. Vyshnevskyi [17] and others).

Owing to digitization, data becomes easily available for use on various platforms, devices, and interfaces.

The Ukrainian (V.D. Chekina [17], O.V. Dannikov [38], O.M. Harkushenko [17], S.I. Kniaziev [17], D.V. Lypnytskyi [17], K.O. Sichkarenko [38], G.O. Tkachuk [39], V.P. Vyshnevskyi [17]) as well foreign researchers (B. Bimber [40], S. Brennen [27], U. Bruegger [41], J. Bumann [28], M. Castells [42], A.J. Flanagin [40], K. Knorr Cetina [41], D. Kreiss [27], M.K. Peter [28], D. Savi [35], C. Stohl [40], J. Van Dijk [36], S. Verhulst [37]) pay their attention to the issue of defining the concept of "digitalization". Based on the analysis, synthesis of experience and research, we understand digitalization as a process of transformation and/or improvement of enterprise activities, business models, business functions, communications, use of online platforms, training and retraining of staff to work in new conditions, etc. based on the widespread use of digital technologies and digitized data.

The issue of defining the concept of "digital transformation" is currently quite relevant in foreign and domestic scientific literature. Research papers [17, 27, 28, 32, 35, 42-47] propose different approaches to the definition of this concept. In our opinion, the approaches do not significantly contradict each other. However, these definitions are not complete enough, in our opinion.

Based on the analysis and synthesis of the concept interpretations, we define digital transformation as fundamental changes in the organizational structure of companies, production, ecosystem, industry as a whole by optimal integration of traditional processes and digital technologies with their gradual implementation at all levels.

The last stage is final in the concept of digital transformation. Owing to its introduction, the modern digital business models and processes are restructuring the economy. Society is also developing and changing when people integrate digital technologies into their life and daily habits [48].

Summarizing the abovementioned considerations, we present the stages of digital transformation (figure 2).

The researches of Cognizant Center for the Future of Work (USA) [50] showed that the rapid development of digital technologies has already affected traditional business processes, IT infrastructure and social life (figure 3).

At the beginning of 2020, production and social life are generally affected by such technologies (figure 4) [50].

Combined digital technologies (shown in figure 3 and figure 4) are increasing their impact on business and social life.

Figure 5 shows the areas in which fundamental changes are expected due to the digital transformation. 


\section{Digital Transformation}

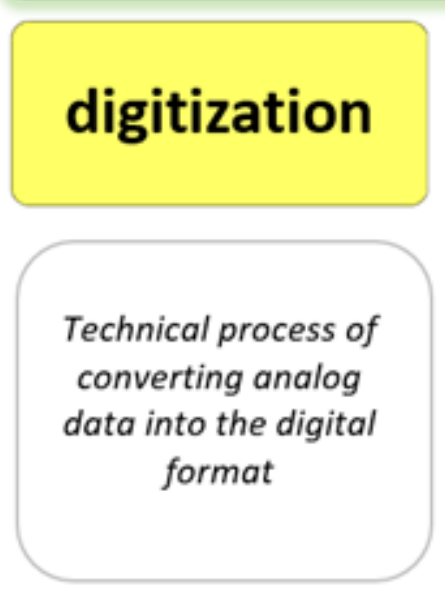

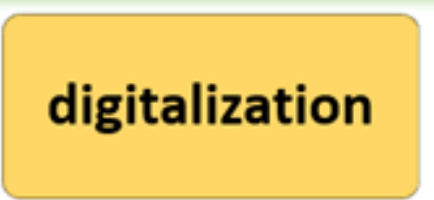

Process of using digital data and digital

technologies to transform communications, business functions, business models, etc.

\section{digital transformation}

Fundamental changes in the organizational structure of a particular industry through the optimal integration of traditional processes with digital technologies

Figure 2. Stages of digital transformation (based on $[48,49]$ ).

(percent of respondents answering "high" or "very high" impact)

Figure 3. Stages of digital transformation. Source: retrieved from https://www.cognizant.com/content/dam/CognizantDotcomimages/monthofhyperdigital transformationfigure2.jpg, (accessed on 19.12.2020)

\section{Development of digital transformation model}

Digital transformation (DT) is the result of digitisation and digitalisation of economies and societies. DT is an ongoing process. The introduction of digital technologies creates both new opportunities and new challenges.

Consider the challenges posed by a process, digital transformation, which is a complex phenomenon of different development. These challenges are related to the following issues:

- which areas are most affected by the digital transformation,

- how the digital transformation affects the labor market, training of future professionals, and social life in general,

- what are the ways to implement digital transformation for different industries, 


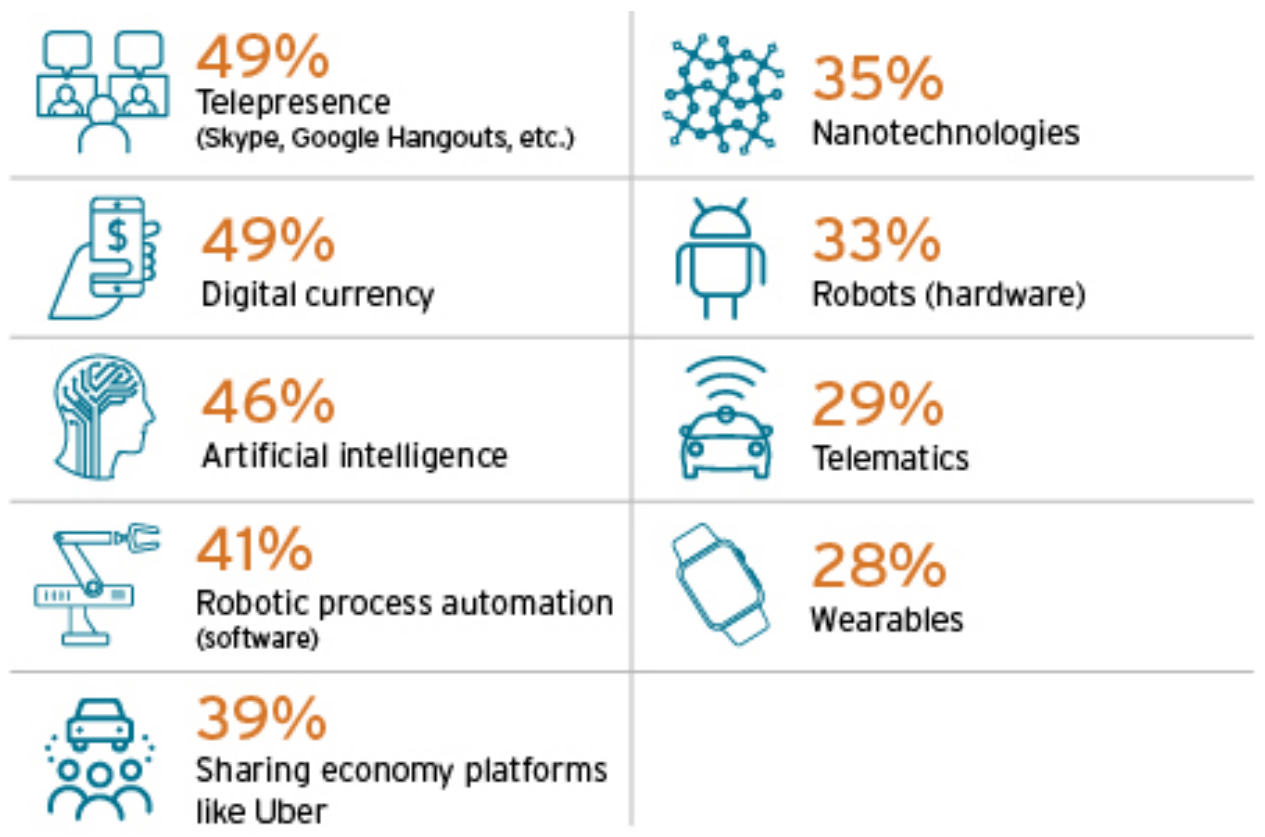

(percent of respondents answering "high" or "very high" impact)

Figure 4. The impact of technology that is the basis for the digital transformation of the economy, production, and social life [50]

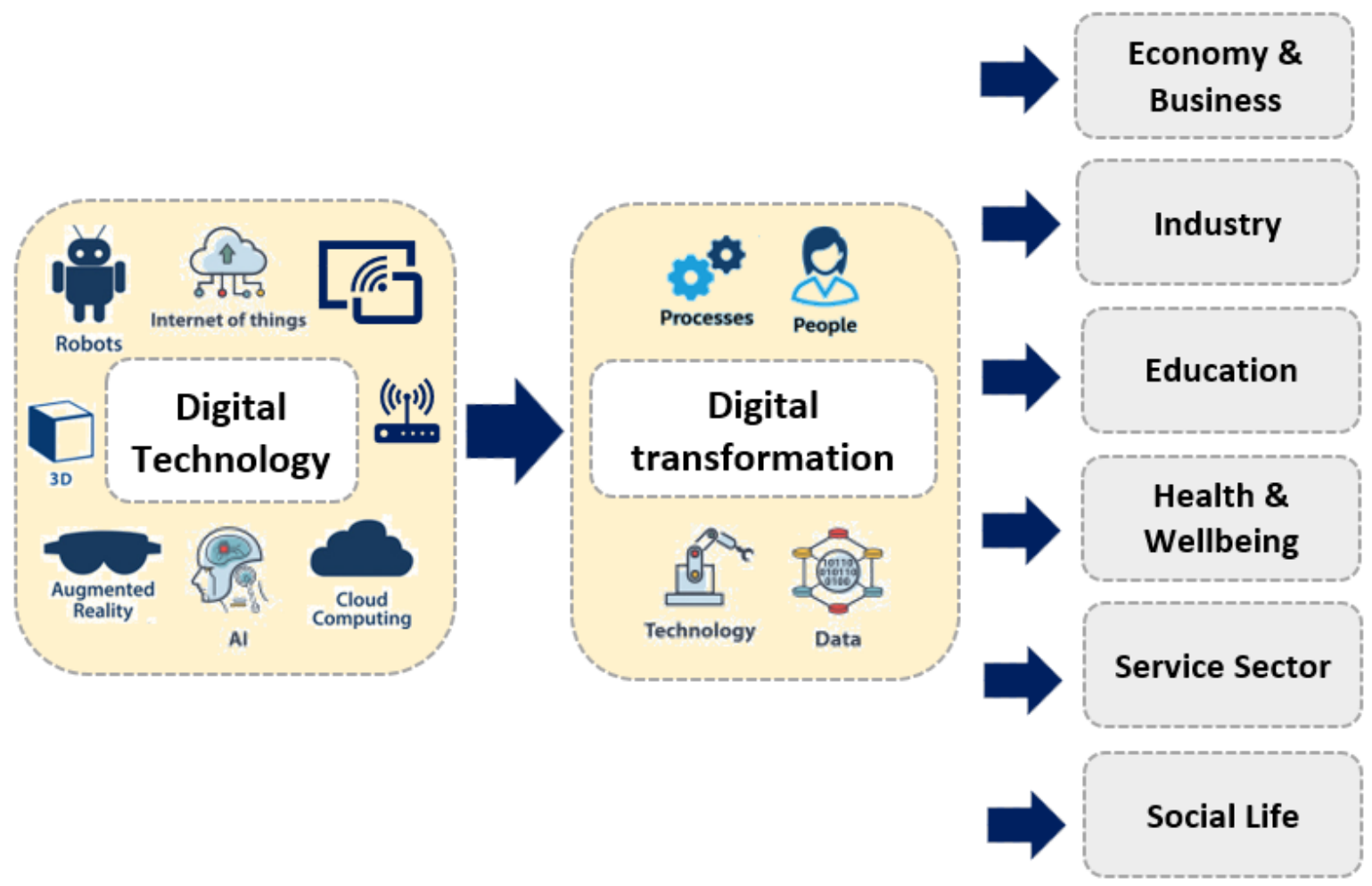

Figure 5. Areas in which fundamental changes take place due to the digital transformation. 
- what steps need to be taken for the digital transformation of companies, production, ecosystem, and a particular industry as a whole,

- what changes in educational systems need to be made to adapt people and accelerate their inclusion into the processes of digital transformation.

One of the key issues for the implementation of digital transformation is changes in the way of thinking and requirements for the competencies of workers in the industry. First of all, it is connected with people's understanding of digital transformation processes and with their ability to use digital technologies effectively.

For specifying Ukrainian educators' awareness level about digital transformation processes, authors have conducted survey. The online survey was elaborated (in Ukrainian) using Google Forms. 78 Ukrainian educators have taken part in the present research (during December 2020). We guaranteed participants that only anonymized data would be shared.

The survey contained information about digital transformation processes in society and education.

The data on the Ukrainian educators' awareness level about digital transformation processes are presented in figures 6-9 below.

Q.: How do you understand the digital transformation?

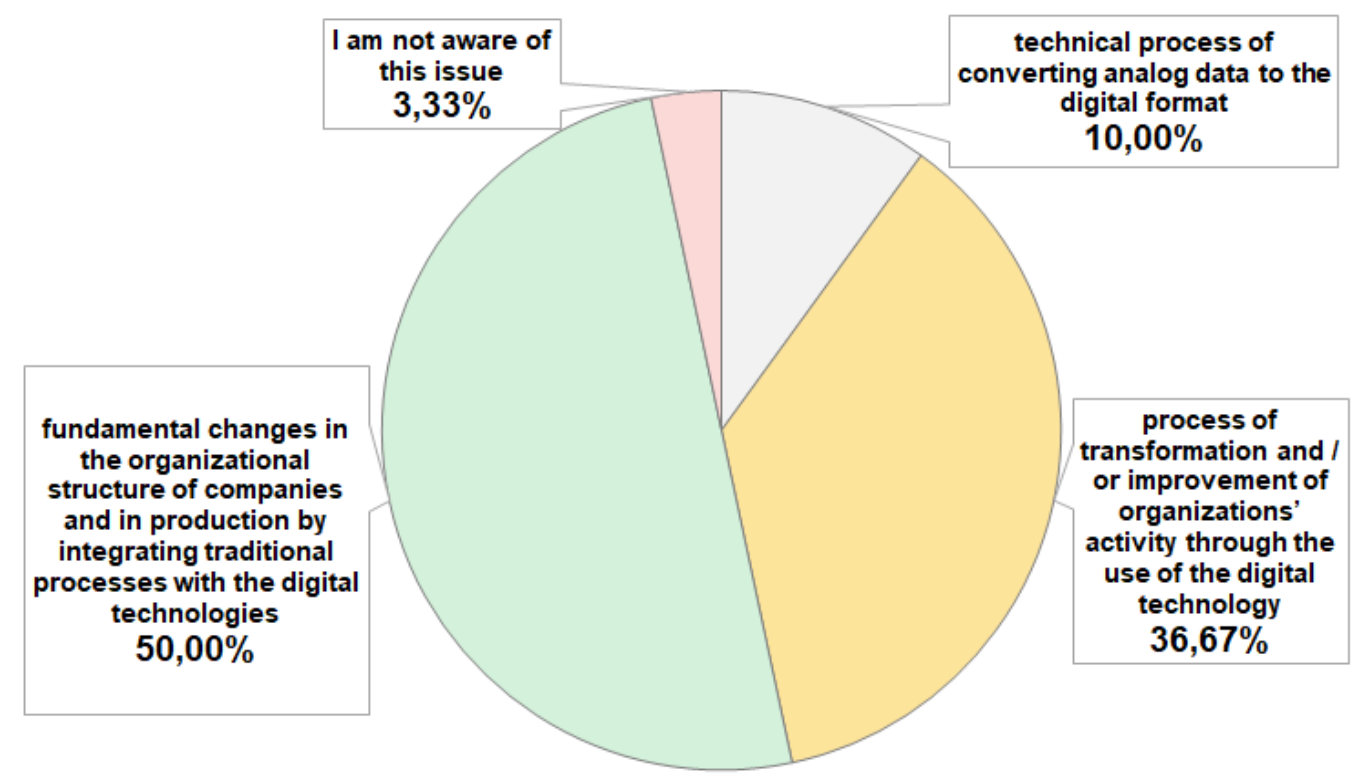

Figure 6. Survey responses on understanding the digital transformation.

As we can see from figure 6, the largest group of respondents (50\%) understands the digital transformation correctly. At the same time, about $37 \%$ of educators have defined the digital transformation as process of transformation and / or improvement of organizations' activity through the use of the digital technology (digitalization). $10 \%$ of respondents have defined it as digitization. This means that there is a need to increase their awareness level about digital transformation processes.

Q.: Is the digital transformation a priority identified at the national level in Ukraine?

Figure 7 are shown that despite the fact that the majority of respondents are aware of this issue (almost 61\%), a large percentage of respondents (39\%) do not know whether the digital transformation a priority identified at the Ukrainian national level or not. This means that there is a need to disseminate these issues at national level, for example to introduce these questions as a part of training and retraining of specialists. especially for educators. 


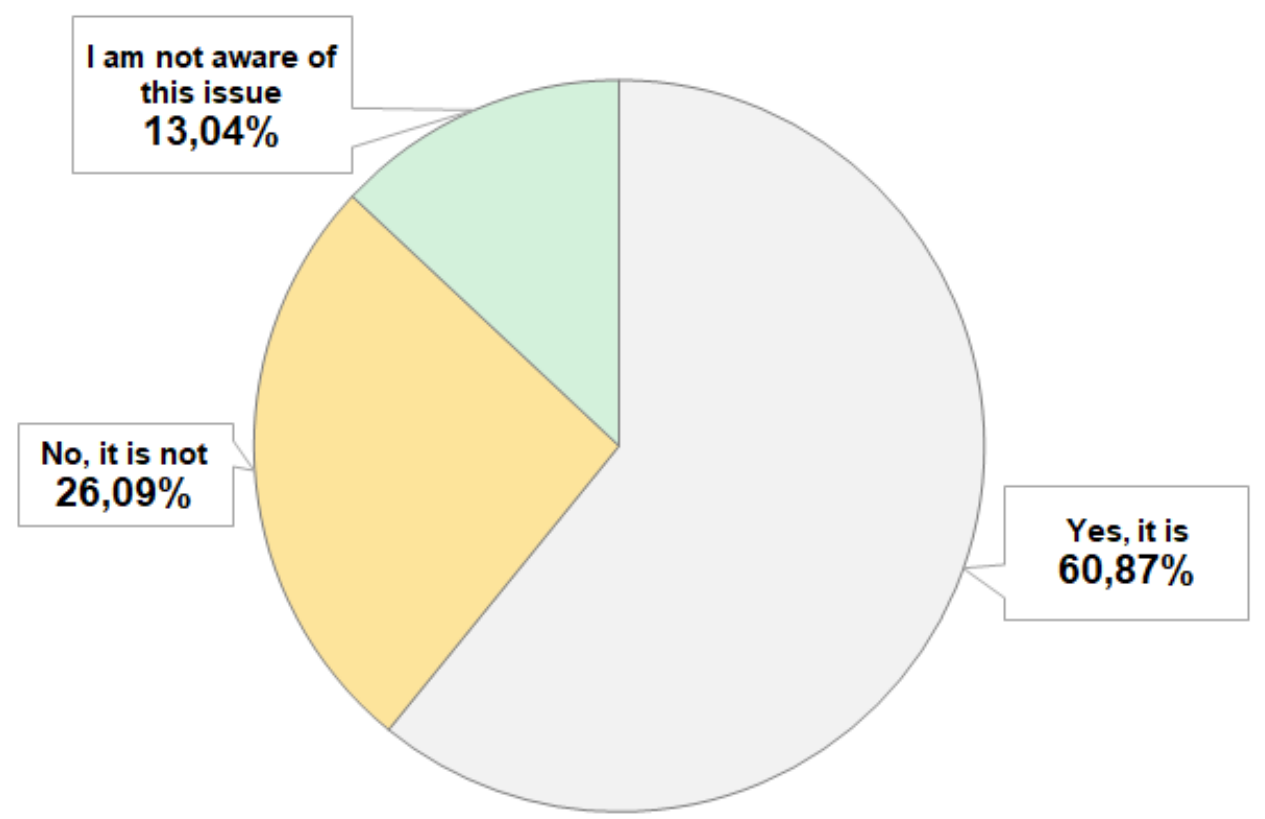

Figure 7. Survey responses on awareness of the respondents about is the digital transformation a priority identified at the national level in Ukraine.

Q.: What are the prerequisites for the digital transformation of society?

Survey responses on prerequisites for the digital transformation of society are shown in figure 8 (multiple answers are possible, that is why the total responses can be more than 100\%):

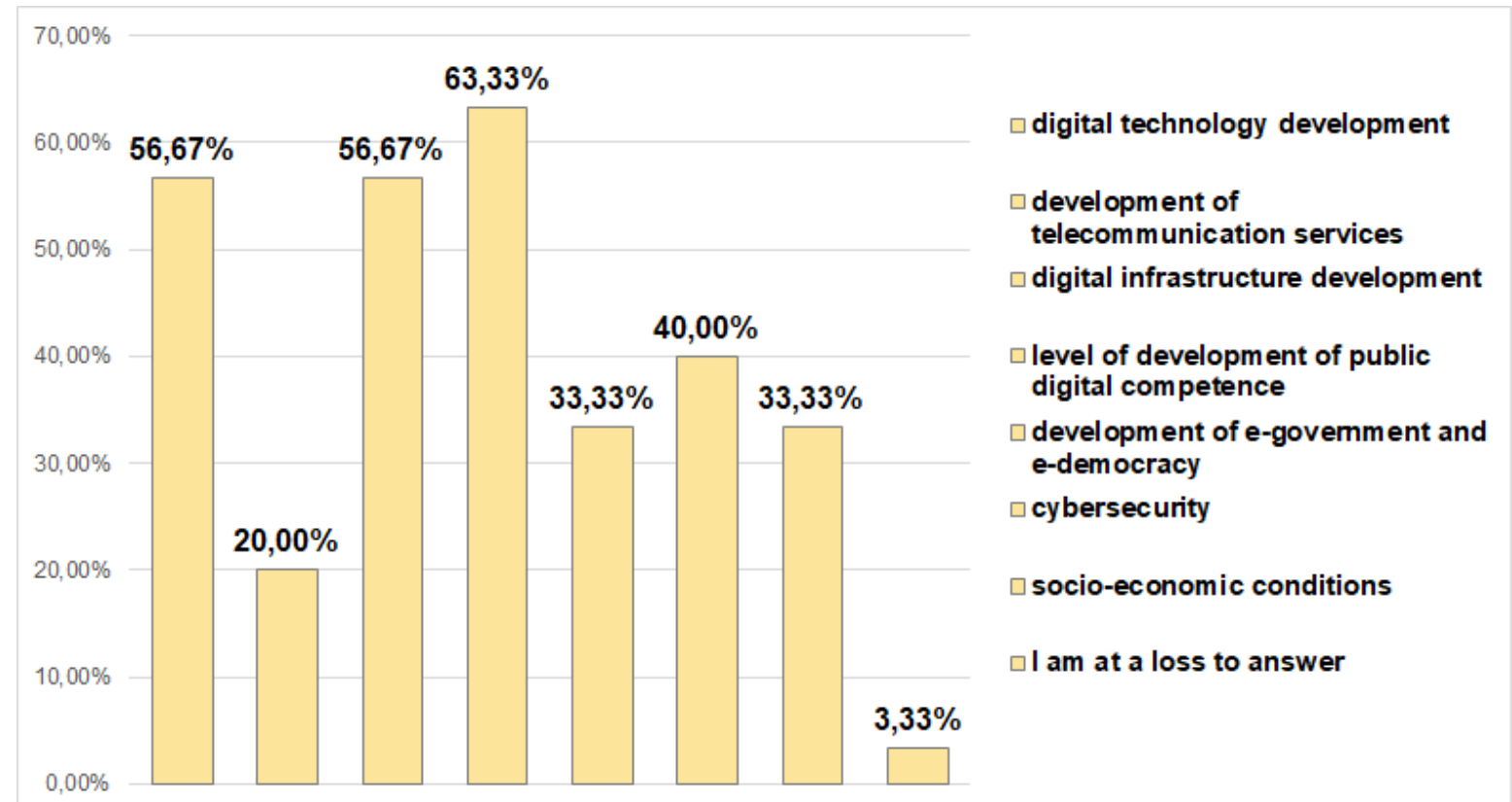

Figure 8. Survey responses on prerequisites for the digital transformation of society.

As we can see from figure 8, the most popular answers are "digital technology development" (57\%), "digital infrastructure development" (57\%) and "level of 
development of public digital competence" (63\%). That means that respondents have defined of the main needs for digital transformation correctly. But citizens also should will know about other needs for digital transformation such as cybersecurity, telecommunication services and e-government and e-democracy development etc.

$Q .:$ What are the most important steps to carry out digital transformation?

The most popular answers are "development of the digital transformation strategy", "ensuring cybersecurity" and "development of a new level of employees' thinking". Second in importance are the following issues: "digitalization of processes", "retraining and advanced training of employees" and "introduction of digital tools in the activities of a particular sector". That means that citizens have general idea about the steps of the digital transformation processes.

Q.: Which of the following causes the digital transformation of education?

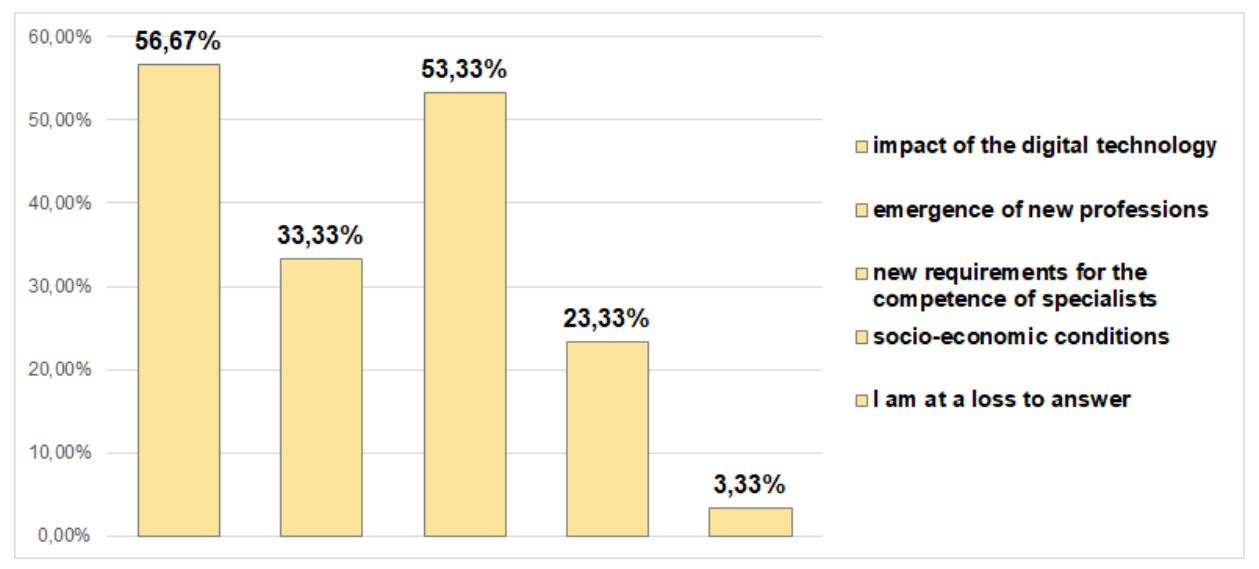

Figure 9. Survey responses on the causes the digital transformation of education.

As we can see from figure 9, the largest group of respondents defines of the digital technology impact $(57 \%)$ and new requirements for the competence of specialists $(53 \%)$ as the main causes the digital transformation of education. At the same time, about $33 \%$ of educators suggest that emergence of new professions also impact on the digital transformation of education.

According to the conducted research we can make conclusion about necessary to increase awareness level of the Ukrainian citizens about digital transformation processes in whole. One of the ways for solve this problem is to development digital transformation model and implementation it to companies, production, ecosystem, industry, education etc.

Now, the topical issue of numerous studies of researchers, economists, public and state specialists, etc. is developing of the digital transformation, through which it will be possible to determine the digital transformation strategies and ways to implement them. Such issues for the digital transformation of various areas are actively explored by the following researchers as J. Bumann [51], M.K. Peter [51] (general research), M.W. Wildan [52], A.I. Umri [52], H.U. Hashim [52], A.R.A. Dahlan [52] (economy, business), J.M. Pawlowski [28], A. Rof [53], A. Bikfalvi [53], P. Marqus [53], T. Muluk [54], T. Nanaeva [55], D. Nguyen [56] (education), I. Mergel [57], N. Edelmann [57], N. Haug [57] (public administration) and others.

Based on the analysis of the considered researches $[28,51-54,56-58]$ the authors of this paper proposed a general model of digital transformation (figure 10).

The main components of this model are:

1. The reasons that lead to the need in digital transformation of the area/industry (the impact of digital technologies, new services, new requirements to life in a digital society, etc.). 


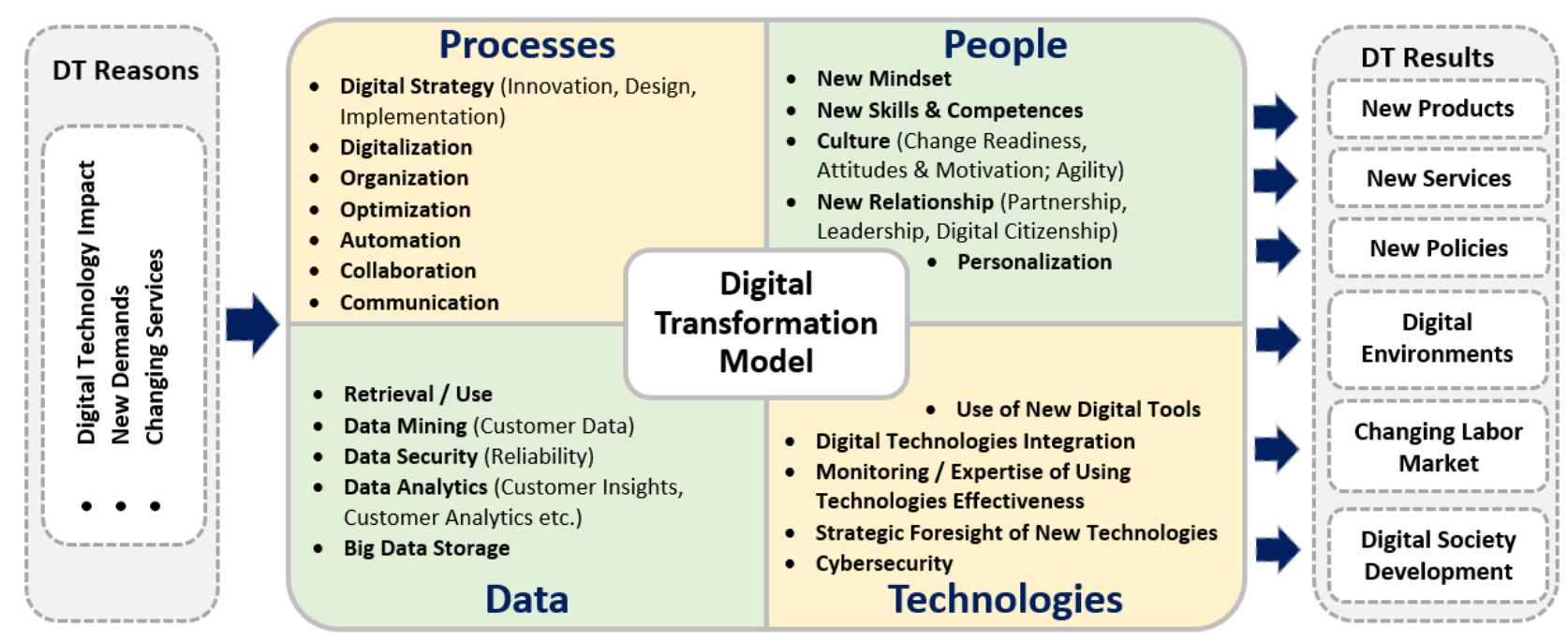

Figure 10. Digital transformation model.

2. The use of digital technologies to change business processes in the industry to increase its efficiency.

3. Preparation of workers, employers, the population as a whole for life in new socio-economic conditions (change of culture, way of thinking, abilities, skills, and mutual relations) and development of their digital competences.

4. Effective use of existing data, including the use of modern tools for their analysis with elements of Artificial Intelligence and Big Data.

5. The main results of digital transformation include new products, services, policies, markets, environment and development of the digital society as a whole.

The proposed model takes into account the goals, digital technologies impact, changing services and new demands. The brief description is below.

Block "Processes":

- Digital Strategy (innovation, design, implementation).

- Digitalization.

- Organization.

- Optimization (paperless trend).

- Automation.

- Virtual collaboration and virtual communication.

Block "People":

- New Mindset (computational thinking, design mindset, emotional intelligence, social intelligence).

- New Skills \& Competences (digital skills \& competences, soft skills, media literacy, transdisciplinary competences).

- Culture (innovation culture, change readiness, attitudes \& motivation for education; lifelong learning, non-formal learning, informal learning; agility).

- New Relationship (partnership, leadership, Digital citizenship).

- Personalization. 


\section{Block "Technologies":}

- Use of New Digital Tools.

- Digital Technology Integration.

- Monitoring / Expertise of Using Technologies Effectiveness.

- Strategic Foresight of New Technology.

- Cybersecurity.

Block "Data":

- Retrieval / Use.

- Data Mining (customer data).

- Data Security (reliability).

- Data Analytics (customer insight, customer analytics etc.)

- Big Data Storage.

\section{Conclusions}

Thus, the results of the digital transformation are new products, services, policies, markets, environment and development of the digital society as a whole. The process of the digital transformation is unavoidable of all spheres of human life. Firstly, for this, we should transform the education.

The main steps for the successful implementation of the digital transformation in education are following:

- creating a modern digital educational environment to provide equal access to quality educational services and resources anywhere, anytime and in order to improve the quality of education,

- digitalization of all components of the educational process,

- effective use of modern digital technologies and data through the development of digital skills and competencies of all education stakeholders,

- formation of new competencies of the educational process participants, i.e., competencies which are necessary for a successful life in the digital society,

- defining requirements for digital competencies of heads of educational institutions and educational policy makers,

- developing special innovative courses for heads of educational institutions, which provided them with an understanding of the concept of digital transformation of education and ways to ensure its,

- introduction of SELFIE in all educational institutions.

In the future, the authors will plan to design the recommendation for building of the digital transformation model of education.

\section{References}

[1] Haranin O and Moiseienko N 2018 CEUR Workshop Proceedings 2292 143-150

[2] Abuselidze G and Mamaladze L 2021 Journal of Physics: Conference Series 1840012040 URL https://doi.org/10.1088/1742-6596/1840/1/012040

[3] Merzlykin P, Kharadzjan N, Medvedev D, Zakarljuka I and Fadeeva L 2018 CEUR Workshop Proceedings $2104359-365$

[4] Goncharenko T, Kushnir N, Valko N and Osipova N 2019 CEUR Workshop Proceedings 2393 132-143

[5] Hrybiuk O, Vedyshcheva O, Lukavyi P, Ivaniuk A and Kulish N 2020 CEUR Workshop Proceedings 2732 770-785 
[6] Valko N V and Osadchyi V V 2021 Journal of Physics: Conference Series

[7] Herts A, Tsidylo I, Herts N, Barna L and Mazur S I 2020 E3S Web of Conferences 16605001 ISSN 25550403

[8] Sverdlova A D, Zaporozhets A O, Bohachev I V, Popov O O, Iatsyshyn A V, Iatsyshyn A V, Kovach V O, Artemchuk V O and Hrushchynska N M 2021 CEUR Workshop Proceedings 2850 57-70 URL http://ceur-ws.org/Vol-2850/paper4.pdf

[9] Lobanchykova N M, Pilkevych I A and Korchenko O 2021 CEUR Workshop Proceedings 2850 83-96 URL http://ceur-ws.org/Vol-2850/paper6.pdf

[10] Kompaniets A, Chemerys H and Krasheninnik I 2019 CEUR Workshop Proceedings 2546 213-223

[11] Chemerys H, Osadchyi V, Osadcha K and Kruhlyk V 2019 CEUR Workshop Proceedings 2393 17-28

[12] Hordiienko V, Marchuk G, Vakaliuk T and Pikilnyak A 2020 CEUR Workshop Proceedings 2731 217-238

[13] Prokhorov O, Lisovichenko V, Mazorchuk M and Kuzminska O 2020 CEUR Workshop Proceedings 2731 $312-327$

[14] Barkatov I, Farafonov V, Tiurin V, Honcharuk S, Barkatov V and Kravtsov H 2020 CEUR Workshop Proceedings 2731 163-175

[15] Domo 2021 Data never sleeps 8.0 URL https://www.domo.com/learn/data-never-sleeps-8

[16] Ford F R and Lobo I 2017 Digital disruption: Development unleashed. multiply innovation, collaboration and impact through digital in international development URL https://tinyurl.com/6cy3duw6

[17] Vyshnevskyi V P, Harkushenko O, Kniaziev S, Lypnytskyi D and Chekina V 2000 Digitalization of Ukraine's economy: transformational potential (Kyiv, NAS of Ukraine, Institute of Industrial Economics: Akademperiodyka)

[18] Trcek D 2019 CEUR Workshop Proceedings 2422 263-273

[19] Kuzminska O, Mazorchuk M, Morze N and Kobylin O 2019 CEUR Workshop Proceedings 2393 53-67

[20] Pinchuk O, Sokolyuk O, Burov O and Shyshkina M 2019 CEUR Workshop Proceedings 2433 90-101

[21] Leshchenko M P, Kolomiiets A M, Iatsyshyn A V, Kovalenko V V, Dakal A V and Radchenko O O 2021 Journal of Physics: Conference Series $\mathbf{1 8 4 0} 012057$ URL https://doi.org/10.1088/1742-6596/1840/1/012057

[22] Negroponte N 1995 Being digital (N.Y.: Vintage Books)

[23] Westerman G, Bonnet D and McAfee A 2014 The nine elements of digital transformation URL https://sloanreview.mit.edu/article/the-nine-elements-of-digital-transformation/

[24] Digital transformation: online guide to digital business transformation URL https://www.i-scoop.eu/digital-transformation

[25] Uvarov A 2018 On the way to the digital transformation of the school (Moscow: Education and Informatics)

[26] Beniger J 1986 The Control Revolution (Cambridge, Mass.: Harvard University Press)

[27] Brennen S and Kreiss D 2014 Digitalization and digitization URL http://culturedigitally.org/2014/09/digitalization-and-digitization

[28] Pawlowski J M 2019 Digital transformation - how to survive in the age of digitization [presentation] conference New Pedagogical Approaches in STEAM Education. September 26-27, 2019. Kyiv (Ukraine)

[29] Edwards P 1997 The closed world: Computers and the politics of discourse in Cold War America (MIT Press)

[30] Feldman T 1997 An Introduction to Digital Media (New York: Routledge)

[31] Manoff M 2006 Portal: Libraries and the Academy 6(3) 311

[32] Owen J 2007 The Scientific Article in the Age of Digitalization (Dordrecht, The Netherlands: Springer)

[33] Pepperell R 2003 The Posthuman Condition: Consciousness beyond the brain (Portland, Oregon: Intellect Books)

[34] Robinson D 2008 Analog Software Studies: A Lexicon ed Fuller M (Cambridge: MIT Press) pp 21-31

[35] Savi D 2019 From digitization, through digitalization, to digital transformation URL https://www.researchgate.net/publication/332111919

[36] Dijk J V 2005 The Network Society: Social Aspects of New Media (London: Sage)

[37] Verhulst S 2002 About scarcities and intermediaries: the regulatory paradigm shift of digital content reviewed The Handbook of New Media (London: Sage Publications) pp 432-447

[38] Dannikov O and Sichkarenko K 2017 Economics and management of the national economy 17 73-79 URL http://www.market-infr.od.ua/journals/2018/17_2018_ukr/15.pdf

[39] Tkachuk G 2019 Economics of the food industry 11(4) $42-50 \quad$ URL https://journals.onaft.edu.ua/index.php/fie/article/view/1545/1764

[40] Bimber B, Flanagin A and Stohl C 2012 Collective Action in Organizations: Interaction and Engagement in an Era of Technological Change (New York: Cambridge University Press)

[41] KnorrCetina K and Bruegger U 2002 American Journal of Sociology 107 905-950 ISSN 00029602, 15375390 URL http://www.jstor.org/stable/10.1086/341045

[42] Castells M 2010 The Rise of the Network Society (Malden, MA: Wiley-Blackwell) 
[43] Knickrehm M, Berthon B and Daugherty P 2016 Digital disruption: The growth multiplier. Optimizing digital investments to realize higher productivity and growth URL https://tinyurl.com/ebhth8h3

[44] Corominas M, Bonet M, Guimer J and Fernndez I 2006 Journal of Radio Studies 13(1) 116-128

[45] Chapco-Wade C 2018 Digitization, digitalization, and digital transformation: Whats the difference? URL https://tinyurl.com/t6rxca4t

[46] Vial G 2019 The Journal of Strategic Information Systems 28(2) 118-144 ISSN 0963-8687

[47] Vogelsang M 2010 Digitalization in Open Economies: Theory and Policy Implications (Physica-Verlag Heidelberg)

[48] Kasenally A 2018 Confused about digital transformation? $\quad$ so was i URL http://blog.reddot.mu/tag/digitalization

[49] Verhoef P C, Broekhuizen T, Bart Y, Bhattacharya A, Qi Dong J, Fabian N and Haenlein M 2021 Journal of Business Research 122 889-901 ISSN 0148-2963

[50] Benedict K 2017 Get ready for the next 40 months of hyper-digital transformation URL https://tinyurl.com/2f59b3de

[51] Bumann J and Peter M 2019 Action fields of digital transformation - a review and comparative analysis of digital transformation maturity models and frameworks Digitalisierung und andere Innovationsformen im Management (Edition Gesowip) pp 13-40

[52] Wildan Zulfikar M, Idham bin Hashim A, Ubaid bin Ahmad Umri H and Ahmad Dahlan A R 2018 A Business Case for Digital Transformation of a Malaysian-Based University 2018 International Conference on Information and Communication Technology for the Muslim World (ICT4M) pp 106-109

[53] Rof A, Bikfalvi A and Marqus P 2020 Sustainability 12(12) 4980

[54] Muluk T 2016 ICT in education for digital transformation iTU Regional Workshop for CIS on Strengthening Capacity Building in the field of Telecommunications/ICT. April 12-14, 2016. Odessa (Ukraine) URL https://tinyurl.com/usvu5tzb

[55] Nanaieva T and Kuzminska O 2013 Informatics and information technologies in educational institutions 6 $75-78$

[56] Nguyen D 2018 Australasian Marketing Journal 26 72-96

[57] Mergel I, Edelmann N and Haug N 2019 Government Information Quarterly 36101385 ISSN 0740-624X

[58] Patton R and Santos R 2018 The next-generation digital learning environment and a framework for change for education institutions White paper Cisco URL https://tinyurl.com/p43ahpv9 